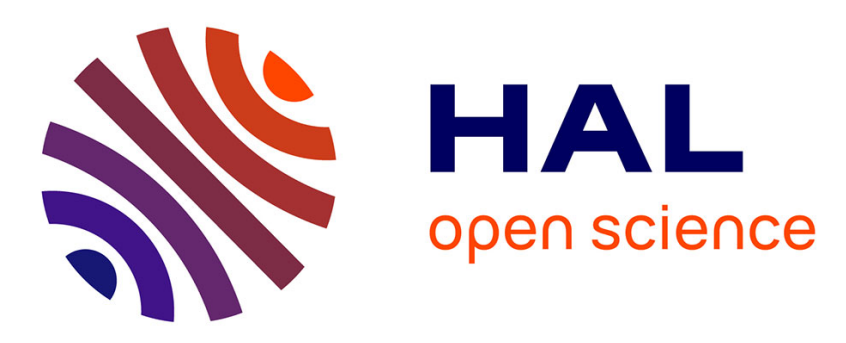

\title{
A Role-Switching Mechanic for Reflective Decision-Making Game
}

Thomas T.C.C. Constant, Axel Buendia, Catherine Rolland, Stéphane Natkin

\section{To cite this version:}

Thomas T.C.C. Constant, Axel Buendia, Catherine Rolland, Stéphane Natkin. A Role-Switching Mechanic for Reflective Decision-Making Game. 14th International Conference on Entertainment Computing (ICEC), Letizia Jaccheri; Konstantinos Chorianopoulos, Sep 2015, Trondheim, Norway. pp.417-423, 10.1007/978-3-319-24589-8_34. hal-01197401

\section{HAL Id: hal-01197401 https://hal.science/hal-01197401}

Submitted on 4 Apr 2018

HAL is a multi-disciplinary open access archive for the deposit and dissemination of scientific research documents, whether they are published or not. The documents may come from teaching and research institutions in France or abroad, or from public or private research centers.
L'archive ouverte pluridisciplinaire HAL, est destinée au dépôt et à la diffusion de documents scientifiques de niveau recherche, publiés ou non, émanant des établissements d'enseignement et de recherche français ou étrangers, des laboratoires publics ou privés.

\section{(c)(1)}

Distributed under a Creative Commons Attribution| 4.0 International License 


\title{
A switching-role mechanic for reflective decision-making game
}

\author{
Thomas Constant ${ }^{1}$, Axel Buendia ${ }^{1}$, Catherine Rolland ${ }^{2}$, and Stéphane Natkin ${ }^{1}$ \\ ${ }^{1}$ CNAM-Cédric, 292 Rue St Martin, FR-75141 Paris Cedex 03 \\ ${ }^{2}$ KTM-Advance, R\&D et Innovation, 42 rue du Faubourg Poissonnière, 75010 Paris \\ \{thomas.constant, axel.buendia, stephane.natkin\}@cnam.fr \\ catherine.rolland@ktm-advance.com
}

\begin{abstract}
This paper introduces issues about a methodology for the design of serious games that help players/learners understand their decisionmaking process. First, we discuss the development of a video game system based on a switching-role mechanic where the player becomes the game leader of the experience. Then, we introduce game mechanics designed to induce a specific behavior, overconfidence, that helps to understand the players' decision-making processes. Finally, we describe tools for measuring the players' self-reflection regarding their judgment process.
\end{abstract}

Keywords: serious game, game design, decision-making, overconfidence

\section{Introduction}

Serious games for decision-making play an important role in management training [1]. But their use is too often limited to the training of a specific behavior, or to learn good habits. Video games offer the possibility of teaching a more reflexive experience [2]. They can be designed as decision-driven systems [3], tools created to help learners reflect on how they play [4], how they interact with the system [5] ; thus, how they make a decision [6]. This paper presents issues about a game design methodology for serious games whose goal is to help learners gain a better understanding of their decision-making process, and to encourage players' reflexivity towards their own decision-making. The design is based on an asymmetrical gameplay: after the player has made a judgment task, and has taken a decision, s/he can become the "game leader"able to influence the other player. By switching roles, s/he may gain a better understanding of his/her own decision process. Our proposal to validate the mechanic's efficiency is to build a video game designed to develop and maintain an excessive confident behavior in the players' judgment, in order to promote the emergence of a reflexive stance of the player towards their decision processes. The first section of this paper introduces our model and its working conditions. The second section explains game mechanics useful for inducing overconfident behavior. These mechanics are, in effect, a translation of cognitive science principles regarding overconfidence into game variables. The third section proposes measurement tools for evaluating the game's efficiency.

\section{Main issue: enlighten the player's decision-making}

\subsection{Switching-role mechanic and operating conditions}

Our main hypothesis is that a switching-role mechanic can help the players to develop a better understanding of their decision-making processes. However, we 
make the assumption that switching-role is not enough: the player can be good at playing but may not necessarily understand of how. To help players to be in a reflexive position about their abilities to make a decision, we introduce three conditions to support the switching-role mechanic:

- A main condition: when switching-role, the player must become the game leader of the game. In this role, s/he can use variables to impact the game experience. The game leader is the one who plays with the mechanics in order to alter the other player's judgment. S/he can achieve an optimal point of view of how the game works, and how it can alter the player's behavior.

- A pre-condition: before becoming the game leader, it is necessary that the player has been in the position of taking a decision for which s/he is confident about. The confidence must be assumed even if the decision was made in an uncertain situation, and may be biased by the context of the game. Players' judgment about their decision must be unequivocal if we want to help them to understand how it can be affected.

- A post-condition: after playing the game leader, it is necessary that the player is able to play his/her first role again, in order to measure the impact of the switching-role mechanic on his/her behavior.

For a serious purpose, we need to help the player to achieve this state of selfreflection. His/her way to make a decision has to be easier to understand and, as a consequence, the decision mechanisms have to be underlined by the system. Our proposal is to use cognitive fallacies in order to highlight judgment processes and explain why the player decision is biased.

\subsection{Heuristic judgment and decision making processes}

Heuristics and biases research allows to understand more precisely human judgment under uncertainty. Confronted with a complex question, decision-makers sometimes unwittingly substitute the question with an easier one. This process, called "attribute substitution", is an example of heuristic operating [7]. A heuristic represents a shortcut in the judgment process as compared with a rational approach to decision-making. Heuristics are "rules of thumbs" - simpler and faster ways to solve a problem, based on knowledge, former experiences, skills, and cognitive abilities (similar to memory or computational ability) $[8,9]$. If heuristic strategies are efficient most of the time, they can, however, occasionally lead to failure comparatively to a rational resolution of the full problem. These errors are called biases: markers of the use of a judgment heuristic. Identifying these markers allows researchers to better understand decision-making processes and reveal heuristic at work. Based on this approach, our methodology entails focusing on a single behavior in order to underline the player's decision-making process chosen specifically because it frequently manifests itself in the comportment of game players: overconfidence.

\subsection{Serious game concept and context of use}

Before introducing specific game mechanics, we present the key elements of a gameplay chosen to illustrate the use of our methodology. The game is played by two players on two different computers. Players cannot see each other and cannot communicate directly, but they are aware of each other presence and 
role in the game. They play a narrative adventure game which apparent goal is to solve a sequence of criminal cases. Each player has a specific role. One of the players adopts the role of an investigator, gathering information to build a hypothesis for a given problem. S/he is confronted with various forms of influence, which are going to have an impact on his/her judgment. The other player personify the game leader, played by the other player, who is going to control the investigator access to information. S/he has access to multiple game variables useful to induce overconfidence in the other player's judgment (see below). After playing a sufficient number of levels in the same role (to be sure that the evaluation of the player's behavior is correct), the players exchange their roles: the game leader becomes the investigator, and reciprocally. By experimenting with these two gameplays, the player puts its own actions into perspective in order to understand how s/he made a decision.

\section{Pre-condition: guiding the player's judgment}

\subsection{Variables to orient the player's confidence}

The overconfidence effect has been studied in economic and financial fields as a critical behavior of decision-makers [10]. It impacts our judgment of both our own knowledge and skills and those of others $[11,12]$. Overconfidence can be explained as a consequence of a person's use of heuristics such as availability and anchoring (defined in Section 3) [13,12]. Overconfidence is also commonly observed in player behaviors. In a card game, for example, beginners as well as experts can be overconfident with regard both to performance and play outcomes [14]. If we want to induce this behavior, the player's judgment has to be driven in a given direction. As a consequence, game mechanics must be related to expressions or sources of overconfidence in human behavior [15]. Then, based on game design methods for directing the behavior of the player $[3,16]$, we derived game mechanics that can be used to produce the overconfidence effect. Figure 1 presents some mechanics examples according to three major expressions of the overconfidence effect.

\subsection{Core gameplay}

At the beginning of the level, the game leader introduces a case to the other player, the investigator. The investigator's mission is to find the culprit: s/he is driven through the level to a sequence of places where his/her is able to get new clues about the case, mainly by questioning non-playable characters. But the investigator is allowed to perform a limited number of actions during a level, losing one each time $\mathrm{s} /$ he gets a new clue. Thus, the investigator is pushed to solve the case as fast as possible. The game leader is presented as the assistant of the investigator, but his/her real role is ambiguous: maybe s/he is trying to help the investigator, or maybe s/he has to push the investigator on the wrong track. This doubt is required to avoid biasing the investigator's judgment about the nature of the influence which target him/her. The investigator should not easily guess what the game leader is really doing, and should stay in a context of judgment in uncertainty. If this is not the case, the measure of the confidence of the player may be distorted. After several levels (several cases), the investigator 


\begin{tabular}{|c|c|c|c|}
\hline & Difficulty & Anchoring & \begin{tabular}{|c|} 
Confirmation \\
\end{tabular} \\
\hline & $\begin{array}{l}\text { A decision-maker can be } \\
\text { overconfident if } \mathrm{s} / \text { he } \\
\text { thinks that the task is } \\
\text { too easy or too difficult } \\
{[13,17] \text {. }}\end{array}$ & $\begin{array}{c}\text { Estimations are based on an } \\
\text { anchor, a specific value they will } \\
\text { easily memorize. The adjustments } \\
\text { will be too far narrowed down } \\
\text { towards this value to give an } \\
\text { appropriate estimation. Anchor } \\
\text { bias can induce overconfidence } \\
\text { when evaluating an item or an } \\
\text { hypothesis }[18,12] \text {. }\end{array}$ & $\begin{array}{l}\text { Confirmation bias } \\
\text { reveals the fact that } \\
\text { decision-makers often } \\
\text { seek evidences that } \\
\text { confirm their } \\
\text { hypothesis, denying } \\
\text { other evidences that } \\
\text { may refute them [19, } \\
12] \text {. }\end{array}$ \\
\hline 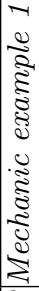 & $\begin{array}{l}\text { Setting up sensitive } \\
\text { difficulty by restricting } \\
\text { the player's exploration } \\
\text { in time and space. }\end{array}$ & $\begin{array}{c}\text { The game designer chooses a } \\
\text { specific piece of information to } \\
\text { use as an anchor. In order for it } \\
\text { to be clear to the player that } \\
\text { s/he has to use it the information } \\
\text { must be important to the case. }\end{array}$ & $\begin{array}{c}\text { The game designer } \\
\text { classifies each piece of } \\
\text { evidence according to } \\
\text { how they support the } \\
\text { investigation's } \\
\text { solution and each of } \\
\text { the red herrings. }\end{array}$ \\
\hline 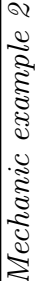 & $\begin{array}{c}\text { Setting up logical } \\
\text { difficulty using puzzle } \\
\text { game design, the } \\
\text { intrinsic formal } \\
\text { complexity of which can } \\
\text { be controlled via given } \\
\text { patterns and parameters. }\end{array}$ & $\begin{array}{l}\text { In order to compare its impact on } \\
\text { player judgment the game leader } \\
\text { sets the anchor at different points } \\
\text { and times in the game. }\end{array}$ & $\begin{array}{l}\text { During the game, } \\
\text { when giving evidence } \\
\text { to the player, the } \\
\text { game leader must } \\
\text { give priority to } \\
\text { evidence that favors a } \\
\text { specific red herring. }\end{array}$ \\
\hline
\end{tabular}

Fig. 1. Variables and game mechanics to orient the player's behavior becomes the new game leader, and vice versa. To win, the investigator must find the probable solution of a case depending on the clues s/he might have seen, associated with a realistic measure of his/her confidence. At the opposite, the game leader wins if $\mathrm{s} /$ he has induced overconfidence in the investigator's judgment, and if the latter didn't discover the game leader role.

\section{Post-condition: measuring the player's behavior}

\subsection{Evaluation of the player's confidence}

Two kinds of evaluations are used to assess the effectiveness of a serious game based on our switching-role model. The first ones focuses on the player's judgment through the evaluation of his/her confidence. Measurements of the investigator's overconfidence are based on credence calculation, which is used in overconfidence measurement studies [17]. This score assesses the players' ability to evaluate the quality of their decision rather than assessing the value of the decision itself. Variations of this score from one game session to an other can show the evolution of the players' confidence regarding their decision-making process. After playing, players must fill out a questionnaire survey in order to give a more precise evaluation of their progression and confidence [20].

\subsection{Evaluation of the player's reflexivity}

The second evaluations highlight the players' ability to assess their self-efficacy in terms of problem solving. Judgment calibration may engage the decision-maker 
in a reflexive posture on his/her ability to judge the quality of his/her decision that the overconfidence effect may bias [21]. But it is not enough for a long-lasting understanding of the behavior [22]. Therefore, in order to extend its effects, we design a re-playable game which can be experienced repeatedly within one or various training sessions. The switching-role mechanic allows the player to engage in a self-monitoring activity, by observing the behavior of other players and by experimenting on them. After several levels from this perspective, the player discerns how the investigator develops overconfidence, or tries to reduce it. Then the player resumes his/her first role and starts by giving new self-evaluations. This time, the player should give a more realistic assessment of his/her ability to solve the case. The variation of the players calibration score can give us a precise measure of the evolution of their behavior, and by extension, of their understanding on how they make a decision in the game. Figure 2 presents the range of possible player behaviors that we can expect.

\begin{tabular}{|c|c|c|}
\hline Not confident & Very confident \\
\hline $\begin{array}{c}\text { The solution } \\
\text { of the case } \\
\text { given by the } \\
\text { player is } \\
\text { improbable }\end{array}$ & $\begin{array}{c}\text { The player is aware of the weakness } \\
\text { of his/her reasoning. Well calibrated } \\
\text { Score multiplied }\end{array}$ & $\begin{array}{c}\text { The player was too quick in } \\
\text { his/her reasoning (and s/he has } \\
\text { failed to seen the limits). S/he } \\
\text { made a mistake in his/her } \\
\text { reasoning. Uncalibrated Player } \\
\text { loses his points }\end{array}$ \\
\hline $\begin{array}{c}\text { The solution } \\
\text { of the case } \\
\text { given by the } \\
\text { player is } \\
\text { probable }\end{array}$ & $\begin{array}{c}\text { The player was too quick in his/her } \\
\text { reasoning (and s/he realizes this). } \\
\text { S/he is correct, but has no } \\
\text { confidence in his/her reasoning. }\end{array}$ & $\begin{array}{c}\text { The player is correct as well as } \\
\text { confident in his/her reasoning. } \\
\text { Well calibrated Score }\end{array}$ \\
\hline
\end{tabular}

Fig. 2. Player behavior matrix

\section{Conclusion and future works}

This paper proposed a game design methodology for building serious games and the way of use to let the players gain a better appreciation of how they make a decision. This methodology is based on the heuristic approach to the analysis of human judgment as well as game design research that relates to decision-making and reflexivity. We then proposed rules and game mechanics designed to induce and control the overconfidence effect and to encourage the players' reflexivity regarding their decision-making. Finally, we introduced the idea of tools for measuring both the players' reflexivity and the effectiveness of the game itself. This methodology is currently being used to develop a prototype of the serious game, which will be evaluated in training courses at the Management \& Society School of the National Conservatory of Arts and $\mathrm{Crafts}^{1}$. The prototype will be able to verify the proper functioning of the switching-role mechanic, its impact and its durability on the player's behavior.

\footnotetext{
${ }^{1}$ For more informations about the School and the Conservatory: http://the.cnam.eu
} 


\section{References}

1. Barth, I., Géniaux, I. (2010). Former les futurs managers à des compétences qui n'existent pas: les jeux de simulation de gestion comme vecteur d'apprentissage. Management \& Avenir, 6(36), 316-339.

2. Constant, T., Buendia, A., Rolland, C., Natkin, S. (2015). Enjeux et problématiques de conception d'un jeu sérieux pour la prise de décision. Revue ISI, 20(1), 107-131.

3. Schell, J. (2008). The Art of Game Design A Book of Lenses (1st ed.). Burlington, USA: Morgan Kaufmann Publishers.

4. Gee, J. P. (2008). Surmise the Possibilities: Portal to a Game-Based Theory of Learning for the 21st Century. In Clash of Realities 2008: Spielen in Digitalen Welten (1st ed., p. 33). Munchen, Deutschland.

5. Papert, S. (1993). Mindstorms: Children, Computers, And Powerful Ideas (2nd ed.). New York, USA: Basic Books, Inc.

6. Shaffer, D. W. (2005). Epistemic Games. Innovate: journal of online education, $1(6)$.

7. Kahneman, D., Frederick, S. (2005). A model of heuristic judgment. In K. J. Holyoak, R. G. Morrison (Eds.), The Cambridge Handbook of Thinking and Reasoning (pp. 267-293). Cambridge,

8. Kahneman, D., Tversky, A. (1974). Judgment under Uncertainty: Heuristics and Biases. Science (New York, N.Y.), 185(4157), 1124-31.

9. Gigerenzer, G., Gaissmaier, W. (2011). Heuristic decision making. Annual Review of Psychology, 62, 451-82.

10. Bessière, V. (2007). Excès de confiance des dirigeants et décisions financières: une synthèse. Finance Contrôle Stratégie, 10, 39-66.

11. Johnson, D. D. P., Fowler, J. H. (2011). The evolution of overconfidence. Nature, 477(7364), 317-20.

12. Russo, J. E., Schoemaker, P. J. H. (1992). Managing overconfidence. Sloan Management Review, 33(2), 7-17.

13. Griffin, D., Tversky, A. (1992). The weighing of evidence and the determinants of confidence. Cognitive Psychology, 411-435.

14. Keren, G. (1987). Facing uncertainty in the game of bridge: A calibration study. OBHDP, 39(1), 98-114.

15. Moore, D. A., Healy, P. J. (2008). The Trouble with Overconfidence. Psychological Review, 115(2), 502-17.

16. Adams, E. (2007). Fundamentals of Game Design. Design (2nd ed.). Berkeley, CA, USA: New Riders.

17. Lichtenstein, S., Fischhoff, B. (1977). Do those who know more also know more about how much they know? Organizational Behavior and Human Performance, 20, 159-183.

18. Kahneman, D., Tversky, A. (1977). Intuitive prediction: Biases and corrective procedures. Eugene, Oregon, USA.

19. Koriat, A., Lichtenstein, S., Fischhoff, B. (1980). Reasons for confidence. Journal of Experimental Psychology: Human Learning and Memory, 6(2), 107-118.

20. Stankov, L., Lee, J. (2008). Confidence and cognitive test performance. Journal of Educational Psychology, 100(4), 961-976.

21. Stone, D. N. (1994). Overconfidence in Initial Self-Efficacy Judgments: Effects on Decision Processes and Performance. OBHDP, 59(3), 452-474.

22. Stankov, L., Lee, J., Paek, I. (2009). Realism of confidence judgments. European Journal of Psychological Assessment, 25(2), 123-130. 